\title{
Experiments in Community Building within Classrooms of Commuter Stu- dents. Part I: The Case of Statics
}

\section{Dr. Josué Njock Libii, Purdue University Fort Wayne}

Josué Njock Libii is Associate Professor of Mechanical Engineering at Indiana University-Purdue University Fort Wayne, Fort Wayne, Indiana, USA. He earned a B.S.E in Civil Engineering, an M.S.E. in Applied Mechanics, and a Ph.D. in Applied Mechanics (Fluid Mechanics) from the University of Michigan, Ann Arbor, Michigan. He has worked as an engineering consultant for the Food and Agriculture Organization (FAO) of the United Nations and been awarded a UNESCO Fellowship. In addition to IPFW, he has taught mechanics and related subjects at many other institutions of higher learning: The University of Michigan, Eastern Michigan University, Western Wyoming College, Ecole Nationale Supérieure Polytechnique, Yaoundé, Cameroon, and Rochester Institute of Technology (RIT). He has been investigating the strategies that help engineering students learn, succeed, and complete their degree programs for many years. He is an active member of two research groups in his department: The Undergraduate Projects $\mathrm{Lab}$ and the Energy Systems Lab. He is currently the PI of an NSF grant titled "Building a Sustainable Institutional Structure to Support STEM Scholars at IPFW", Award Number:1565066. 


\section{Experiments in Community Building within Classrooms of Commuter Students. Part I: The Case of Statics}

\section{Introduction}

A commuter student has been defined as "a college student who does not live in an on-campus institutionally-owned/approved housing, such as a residence hall or a fraternity or sorority house [1]. Using this definition, it has been estimated that approximately $85 \%$ of today's students in the USA commute to campus [2].

The lives of commuter students have three separate parts: life at home, life at work, and life at school. Juggling the responsibilities from those three aspects of their lives is challenging [3]. In many cases, the demands of home life and those of work life do not always allow commuter students to attend their classes regularly and, even when they do, they leave shortly thereafter to go to work or to go home to meet other obligations. These types of students end up spending little or no time on campus with their classmates and fellow students and hence do not participate fully in enriching extracurricular activities that are available on campus [4]-[6]. This happens despite the fact that colleges and universities, in general, offer many opportunities for getting involved in the life of the campus.

At our institution, for example, students have many opportunities for extracurricular activities: to develop leadership skills, to participate in community service, student government, and intramurals, for example. There are more than 140 student organizations and clubs that include the following categories: sports (3), departmental (42), diversity/cultural (12), honorary (15), religious (9), social Greek (3), and special interest (24). It is believed that participation in such activities allows students to feel part of the campus community [14]. Nevertheless, at our institution, most students cannot avail themselves of opportunities to participate in extracurricular activities.

\section{A different approach to getting students involved}

Group work in lecture courses can be used as a means of getting students to interact with each other. Group work is common in laboratory courses, where, generally, data collection is done in groups during lab sessions and it is the writing of the lab reports that is done outside of the lab. However, in lecture courses, which constitute the vast majority of credit hours (about $95 \%$ in the four ABET accredited engineering programs in our college), students are not ordinarily required to work in groups. In the case of commuter students, where other life commitments are such that they must spend limited time on campus outside of scheduled classes, using lecture assignments as a means to give students an opportunity to work together presents a good opportunity for community building. Our experience is that, if the groups are small, three to four members, and ample time is allowed between the date when work is assigned and the date when it is due, it is 
almost always possible for students to find common times when they can get together to do their shared work. Some groups meet face-to-face, others meet online, still others do both.

To utilize this opportunity, the author started creating activities that would be done in small groups outside the classroom during times that were set, and mutually agreeable to, by the all members of a given group; the hope was to build small learning communities (herein referred to as micro communities of learning) among classmates using the time that commuter students were able and willing to spend on campus, off campus, or online.

This paper discusses how this concept was implemented in a class taught on Engineering Mechanics: Statics, at Purdue University Fort Wayne, Fort Wayne, Indiana, in the fall of 2018. It also summarizes the results that were obtained.

\section{Description of the activities}

This section describes the approach that was followed; the course in which the activities were used, including its prerequisite and co-requisite; the group problem that was assigned; and the form used by participating students to evaluate the whole experience of working with their classmates.

i) The Approach. Although the purpose of the course was to teach mechanics, we also wanted to intentionally create a welcoming climate and a way for commuting students to know, work with, and support each other in our classroom environments. To this end, we employed a variety of strategies in lecture courses. In the strategy described in this paper, we devised special course assignments: we gave a group problem to the students in a given course on the first day of class and organized students in groups of three or four, depending on the size of the class. Groupings of students were alphabetical, based on the first letter of their last names. The student at the top of each grouping was designated the convener and leader of the group. Students were asked to meet weekly and work collaboratively to solve the assigned problem(s) as a group and to submit one report of their work as a group on the last day of class, which is about one week before the day of the final exam. This report was worth $10 \%$ of the course grade. Students were encouraged to collaborate on other assignments, as their interests and availability allowed them. Solutions of the assigned problems always required analyses using materials learned in the course, validation of the results of analyses through testing in the lab, and an assessment of the extent to which experiments validated their analyses. Students were also given a form on which they were required to record the contributions of each of their teammates to the work of the group; they also reported their personal opinions regarding the extent to which work on the group problem helped them learn the course materials on which the problem was based as well as the extent to which working with their assigned group helped them feel supported by members of their team.

ii) Descriptions of the course, its prerequisite, and co-requisite. The course name: Statics (CE 250 and ME 250). Description from the University Bulletin: "Forces and couples, free body diagrams, two- and three-dimensional equilibrium of a particle and rigid bodies. Principles of 
friction, centroids, centers of gravity, and moments of inertia. Virtual work, potential energy, and static stability of equilibrium. Internal forces, shear and bending moment diagrams." Semester credit hours: 3; Class hours: 3. Prerequisite: Physics 152, Co-requisite: MA 261.

Prerequisite: Physics 152. Description from the University Bulletin: "Statics, uniform, and accelerated motion; Newton's laws; circular motion; energy, momentum, and conservation principles; dynamics of rotation; gravitation and planetary motion; properties of matter; simple harmonic and wave motion; sound." Semester credit hours: 5; class hours: 6 - lecture 4, lab 2.

Co-requisite: Math 261. Description from the University Bulletin: "Solid analytic geometry, vector calculus, partial derivatives, and multiple integrals. Semester credit hours: 4. Class hours: 4.

\section{iii) The group problem assigned in Engineering Mechanics: Statics - during fall 2018}

Title. To Slip or Not to Slip: Test and evaluate the "Nonslip" property of rug pads.

A. Introduction. When a rug is in direct contact with a bare surface, it can slip relative to that surface. According to their manufacturers, rug pads are created and used to prevent such slipping. You work for a supply chain that wants to purchase and sell large quantities of rug pads. You are given a piece of material that is purported to prevent slippage. Test and evaluate the claim that the material of which the rug pads are made prevents slipping.

B. Design three tests: Test 1 . Test the carpet, or some other material, without the pad under it. Test 2. Test the same materials (rugs, or others) with pads under them but without other loads on the pad than the weight of the "rug". Test 3. This test is similar to test 2, except that there is a load on the carpet. Test at least five different magnitudes of loads.

C. Collection of data. Determine and collect the data that you need in each test.

D. Interpretation of data. Interpret the data that you collected.

E. Evaluation of the claim. Use the interpretation of the data that you collected to evaluate the claim: To what extent is the claim true? To what extent is the claim false? Do your conclusions depend on the magnitude of the load on the carpet?

F. Write a report that covers items $\mathrm{B}, \mathrm{C}, \mathrm{D}$, and $\mathrm{E}$.

G. Grading: Part B (20 points); Part C (20 points); Part D (20 points); and Part E (40 points).

Note. A copy of the actual problem statement, as given to students in class, is shown in appendix 1.

iv) Description of the form used by students to evaluate the group-problem experience. The form used for the evaluation of the contribution of teammates and of the group experience itself consisted of the elements that are shown below.

Identifiers: "Group Number: Evaluator's name: 
Peer Evaluation: Please, evaluate the quality and quantity of the contribution of each of your teammates, using the four categories shown below: Effort put into the project; Cooperation provided; Support provided; and Share of Work done. Each criterion is worth a maximum of 10 points. Please, score each criterion out of ten. You may add comments, if you wish. Add another sheet, if necessary.

Name of Teammate No. 1, or 2, or 3:

Effort put into the project $($ maximum $=10)$; Cooperation provided $($ maximum $=10)$;

Support provided $($ maximum $=10)$; Share of work done $($ maximum $=10)$;

Total score $(\max =40)$ : $\quad$ Calculate the percentage (total score $* 100 / 40)$ :

Contribution of the Group Problem to learning the materials on which the problem was based.

Please, score, $(\operatorname{maximum}=10)$ :

Contribution of the Group Problem to the building of a classroom community. Please, score, (maximum $=10)$ :

Comments:

Note. A copy of the actual form given to students in class is shown in appendix 2 .

Collected data and results. The completed forms were collected and the data were compiled and summarized. A summary of the results obtained is shown below.

1. Number of participating students at the beginning of the semester: 36 .

2. Number of participating students at the end of the semester: 33 .

3. Average score earned by all groups from the group problem: 95/100 (maximum: 100, minimum: 73).

4. Average score earned by all students in quizzes and exams: 70.5/100 (maximum: 100, minimum: 42).

5. Average score on the contribution of the group problem to learning: 8.7/10 (maximum 10, minimum: 0).

6. Average score on the contribution of the group problem to building community: 8.0/10 (maximum 10, minimum: 3 ).

7. Comments and observations on the role of the exercise in building a micro community of learning:

- Each student came to know at least two other students by name, because of the group work.

- Each student had the opportunity to work with at least two other students during the semester.

- About 93 percent of the students worked with a student they had not worked with before registering for the course. 
- About 83 percent of the students worked with a fellow student they did not know before registering for the course.

- Ordinarily, to the author's experience, students who are performing poorly into the middle of the semester tend to start skipping classes and, generally, withdraw from the course before the last day set by the university for dropping courses. Instead, it was observed that many students who were enjoying their groupproject experience were still attending classes regularly and did not drop the course, even though their performances in tests and quizzes were inadequate and were likely to result in very low grades. And, indeed, in the end, even though such students did well in the group problem, their performances yielded grades of $\mathrm{D}$ and $\mathrm{F}$. We hypothesized that such persistence was partially due to the success they were experiencing with their work on the group project and to the support these students were receiving from their teammates.

Some issues arose, however:

1. Some students reported that their teammates $(8.34 \%)$ did not do their share of the work, as required.

2. Three students out of $36(8.34 \%)$ withdrew from the course and did not complete it.

3. Two of the three students who withdrew from the course did so without informing their teammates.

4. One student complained frequently about the open-ended nature of the assignment.

5. One student complained about the fact that working groups had to gather materials for the validation of their analyses on their own and about having to design experiments on their own.

6. Five students were not pleased and grumbled openly about the fact that they were required to write a report in a lecture course on mechanics.

\section{Discussion and Conclusions}

One can legitimately wonder about the relevance of this type of assignment in a Mechanics class. In our experience, the relevance of the assignment is threefold. It is relevant 1) as an application of theory: many students are attracted to engineering because they are "doers"; they want to make things, and so, they want to see how what they are learning is applicable in the so-called "real world"; 2) as a hands-on exercise: many others learn best by getting their "hands dirty"; they are somewhat bored with analysis alone but become truly alive and interested when they have to build and test something; and 3) as a means to let students interact with each other: it is important for students to make connections with other students in the same course and on campus, but many are hesitant to reach out to others on their own. Oftentimes, some students in a given class do not know anyone else in that class and can easily feel isolated; this type of assignment facilitates such connections and mitigates against potential isolations. Indeed, the literature has many references to the need for and importance of such connections to academic success. 
Morrow and Ackerman found that $65 \%$ of students who leave their university depart for nonacademic reasons and that academic progress and achievement are closely related to a sense of belonging [10]. Research has shown that one predictor of persistence in college is feeling a sense of mattering and belonging [1], [37]. Commuter students are particularly at risk of not persisting [1]. Mattering is defined as "the feeling one has when he/she feels that he/she is noticed, cared about, needed, and valued by another person" [12] and the sense of belonging as "the perception of peer and faculty support, classroom comfort, and isolation [3], [11], [38]-[40].

The challenge is how one goes about creating campus environments and associated cultural practices that facilitate connections and make students feel that they belong and that they matter [32], [38]-[40]. Extracurricular activities are clearly one way to do so. But learning communities are also a way to do so [17]-[19]. A learning community can be defined in simple terms as a group of people with common academic goals, who meet on a regular basis to collaborate on classwork. Such communities have been in existence and have been studied for decades; they have also become a trusted way to connect learners [26]-[35]. There are many examples of such communities in existence, particularly at universities with large residence halls [36].

A different challenge arises in adapting the concept of learning communities to campuses where most students are commuters, who have many obligations off campus that preclude spending much time on campus after they leave their scheduled classes [1], [9]. One example of such a commuter campus is where the project described in this article was run, Appendix 3. One possible instrument that can be used to start building community in such an environment is the introduction of group work in lecture classes, provided that the groups are small and ample time is allotted between when the work is assigned and when it is due. In the author's experience, in addition to well-crafted and appropriately-focused assignments, small group sizes and large intervals of time between the date on which work is assigned and the date on which it is due are required. They combine to give students the flexibility they require to gather what they need, to secure the necessary space on campus or off campus, and to make workable arrangements for common dates and times on which to work together; to know each other; and to support each other, while working toward a common goal. That is one way to begin community building among commuter students.

Note: This work is supported by the National Science Foundation (NSF) through NSF Award \#1565066. However, the opinions expressed in this document are those of the author and do not, necessarily, reflect those of the National Science Foundation. 


\section{References}

[1]Jacoby, B. (1989). The student as commuter: Developing a comprehensive institutional response. ASHE-ERIC Higher Education Report No. 7. Washington, DC: School of Education and Human Development,The George Washington University. ED 319298.

[2]National Center for Educational Statistics, 2009)

[3]Jacoby, B (2000). Why involve commuter students in learning? In M. Kramer (Series Ed.), \& B. Jacoby (Vol. Ed.), New directions for higher education, 109. Involving commuter students in learning (pp. 3-13). San Francisco: Jossey-Bass.

[4]Astin, A. W. (1984). Student involvement: A developmental theory for higher education. Journal of College Student Personnel, 25, 297-808.

[5]Astin, A. W. (1999). Student involvement: A developmental theory for higher education. Journal of College Student Development, 40(5), 518-529.

[6] Alfano, H. J., \& Eduljee, N. B. (2013). Differences in work, levels of involvement, and academic performance between residential and commuter students. College Student Journal, 47(2), 334-342.

[7]Tinto, V. (1975). Dropout from higher education: A theoretical synthesis of recent research. Review of Educational Research, 45, 89-125.

[8]ACT. (2013). National collegiate retention and persistence to degree rates. Retrieved January 1, 2014, from http://www.act.org/research/policymakers/pdf/retain 2013.pdf

[9]Baum, E. (2005). Meeting the needs of the overlooked majority. Commuter Perspectives, 29(3), 2 $3,5-8$.

[10]Morrow, J. A., \& Ackermann, M. E. (2012). Intention to persist and retention of first-year students: The importance of motivation and sense of belonging. College Student Journal, 46(3), 483-491.

[11]Tovar, E., Simon, M. A., \& Lee, H. B. (2009). Development and validation of the college mattering inventory with diverse urban college students. Measurement and Evaluation in Counseling and Development, 42(3), 154-178.

[12]Schlossberg, N. K. (1989). Marginality and mattering: Key issues in building community. In D.C. Roberts (Ed.), Designing campus activities to foster a sense of community (pp. 5-15). New Directions for Student Services, No. 48. San Francisco: JosseyBass.

[13] Berger, J. B., Ramírez, G. B., \& Lyons, S. (2012). Past to present: A historical look at retention. In A. Seidman (Ed.), College student retention: Formula for student success (pp. 7-34). Lanham, MD: Rowman \& Littlefield.

[14]Student Life and Leadership at PFW https://www.pfw.edu/student-life/student-organizations/ [15]Purdue University Fort Wayne by the Numbers. https://www.pfw.edu/about/numbers/

[16]Tinto, V. (1997). Classrooms as communities: Exploring the educational character of student persistence. Journal of Higher Education, 68(6), 599-623.

[17]Mitchell, C., \& Sackney, L. (2000). Profound improvement: Building capacity for a learning community. Lisse, Netherlands: Swets \& Zeitlinger.

[18]Rutter, M., \& Maughan, B. (2002). School effectiveness findings 1979-2002. Journal of School Psychology, 40, 451-475.

[19]Huffman,J.B. \& Hipp, K.K. (2003). Reculturing schools as professional learning communities. Lanham, MD: Scarecrow

[20]Stoll, L., Fink, D. \& Earl, L. (2003). It's about learning (and it's about time). London: Routledge Falmer.

[21]Rovai, A. P., Wighting, M.J., \& Lucking, R. (2004). The Classroom and School Community Inventory: Development, refinement, and validation of a self-report measure for educational research. Internet and Higher Education, 7(4), 263-280. 
[22]Overbaugh, R., \& Lin, S. (2006). Student characteristics, sense of community, and cognitive achievement in web-based and lab-based learning environments. Journal of Research on Technology in Education, 39(2), 205-223.

[23]Wighting, M. J. (2006). Effects of computer use on high school students' sense of community. The Journal of Educational Research, 99 (6), 371-379.

[24] Center for American Progress (2006). Retrieved May 17, 2009 from

http://www.americanprogress.org/issues/2006/07/b1982011.html

[25]Wighting, Mervyn; Nisbet, Deanna; and Spaulding, Lucinda S., "Relationships between Sense of Community and Academic Achievement: A Comparison among High School Students" (2009). Faculty Publications and Presentations. 147. http://digitalcommons.liberty.edu/educ fac pubs/147

[26] Lave, J. (1988) Cognition in practice: Mind, mathematics and culture in everyday life. Cambridge: Cambridge University Press.

[27] Brown, J. S., Collins, A., \& Duguid, P. (1989) Situated cognition and the culture of learning. Educational Researcher, 18(1), pp32-42.

[28]Gabelnick, Faith; MacGregor, Jean; Matthews, Roberta S.; Smith, Barbara Leigh (1990). Learning Communities: Creating Connections Among Students, Faculty, and Disciplines. New Directions for Teaching and Learning. 41. Jossey-Bass. ISBN 978-1-55542-838-9.

[29]Lave, J., \& Wenger, E. (1991). Situated learning: Legitimate peripheral participation. Cambridge: Cambridge University Press.

[30] Senge, P., Kleiner, A., Roberts, C., Ross, R., Smith, B. (1994), The fifth discipline fieldbook: strategies and tools for building a learning organization, New York, Currency 1994.

[31] Roth, W.-M., \& Bowen, G. M. (1995) Knowing and interacting: A study of culture, practices, and resources in a grade 8 open-inquiry science classroom guided by a cognitive apprenticeship metaphor. Cognition and Instruction, 13, $73-128$.

[32] Smith, Barbara Leigh; McCann, J., eds. (2001). Reinventing Ourselves: Interdiciplinary Education, Collaborative Learning, and Experimentation in Higher Education. Bolton, MA: Anker Publishing.

[33]Angehrn, Albert A.; Gibbert, Michael (2008). "Learning Networks - Introduction, Background, Shift from bureaucracies to networks, Shift from training and development to learning, Shift from competitive to collaborative thinking, The three key challenges in learning networks".

[34] J. Scott Armstrong (2012). "Natural Learning in Higher Education". Encyclopedia of the Sciences of Learning. [35]Bressman, H., Zellmer-Bruhn, M. (2013) The Structural Context of Team Learning: Effects of Organizational and Team Structure on Internal and External Learning, Organization Science Vol. 24, No. 4, July-August 2013, pp. 11201139

[36] Michigan Learning Communities https://admissions.umich.edu/academics-majors/learningcommunities

[37]Hoffman, M., Richmond, J., Morrow, J., \& Salomone, K. (2002). Journal of College Student Retention, 4(3), 227-256.

[38]Jacoby, B., \& Garland, J. (2004). Strategies for enhancing commuter student success. Journal of College Student Retention, 6(1), 61-79.

[39]Baumeister, R. F., \& Leary, M. R. (1995). The need to belong: Desire for interpersonal attachments as a fundamental human motivation. Psychological Bulletin, 117(3), 497-529.

[40]Buote, V. M., Pancer, S. M., Pratt, M. W., Adams, G., Birnie-Lefcovitch, S., Polivy, J., \& Wintre, M. G. (2007). The importance of friends: Friendship and adjustment among 1st -year university students. Journal of Adolescent research, 22(6), 665- 689. doi: 10.1177/0743558407306344. 
Appendix 1. Statement of the group problem assigned.

\section{The group problem assigned in Engineering Mechanics: Statics during fall 2018}

To Slip or Not to Slip: Test and evaluate the "Nonslip" property of rug pads

\section{A. Introduction}

When a rug is in direct contact with a bare surface, it can slip relative to that surface. According to their manufacturers, rug pads are created and used to prevent such slipping.

You work for a supply chain that wants to purchase and sell large quantities of rug pads. You are given a piece of material that is purported to prevent slippage. Test and evaluate the claim that the material of which the rug pads are made prevents slipping.

\section{B. The tests}

Design three tests:

Test 1. Test the carpet, or some other material, without the pad under it.

Test 2. Test the same materials (rugs, or others) with pads under them but without other loads on the pad than the weight of the "rug".

Test 3. This test is similar to test 2, except that there is a load on the carpet. Test at least five different magnitudes of loads.

\section{Collection of data}

Determine and collect the data that you need in each test

\section{Interpretation of data}

Interpret the data that you collected.

\section{E. Evaluation of the claim.}

Use the interpretation of the data that you collected to evaluate the claim:

To what extent is the claim true?

To what extent is the claim false?

Do your conclusions depend on the magnitude of the load on the carpet?

\section{F. Write a report that covers items B, C, D, and E.}

Grading: Part B (20 points); Part C (20 points); Part D (20 points); Part E (40 points). 
Appendix 2. Description of the form used by students to evaluate the group-problem experience

Form used for the Evaluation of the Contribution of Teammates and of the Group Experience

Group Number:

Evaluator's name:

A. Peer Evaluation: Please, evaluate the quality and quantity of the contribution of each of your teammates, using the four categories shown below: Effort put into the project; Cooperation provided; Support provided; and Share of Work done. Each criterion is worth a maximum of 10 points. Please, score each criterion out of ten. You may add comments, if you wish. Add another sheet, if necessary.

Name of Teammate No. 1:

Effort put into the project (maximum $=10$ ).

Cooperation Provided (maximum $=10)$.

Support Provided (maximum $=10$ ).

Share of Work Done (maximum $=10$ ).

Total score $(\max =40)$ : $\quad$ Calculate the percentage (total score $\left.{ }^{*} 100 / 40\right)$ :

Comments:

Name of Teammate No. 2:

Effort put into the project (maximum $=10$ ).

Cooperation Provided (maximum $=10)$.

Support provided $($ maximum $=10)$.

Share of Work Done $($ maximum $=10)$.

Total score $(\max =40)$ : $\quad$ Calculate the percentage (total score $\left.{ }^{*} 100 / 40\right)$ :

Comments:

Name of Teammate No. 3:

Effort put into the project (maximum $=10)$.

Cooperation Provided (maximum $=10)$.

Support provided $($ maximum $=10)$.

Share of Work Done $($ maximum $=10)$.

Total score $(\max =40)$ : $\quad$ Calculate the percentage (total score ${ }^{* 100 / 40)}$ :

Comments:

B. Contribution of the Group Problem to Learning

Please, score the contribution of this group problem to learning the material from 1 to 10 (max):

C. Contribution of the Group Problem to Building a Classroom Community.

Appendix 3. The context of the project and the challenges facing the university

Purdue University Fort Wayne (PFW) is a regional campus of Purdue University. It is a metropolitan university that is located in Fort Wayne, Indiana, in the Northeast corner of the state. PFW is classified as nonselective; the vast majority of its students (about $92 \%$ ) commutes 
to campus and receives financial aid from a variety of sources. In addition, $48.5 \%$ of the student body is first-generation college students. While by its nature PFW offers great opportunities to participate in higher education to the people of Northeast Indiana and their children, these opportunities come with huge challenges regarding the retention of admitted students and their wherewithal to complete their academic degrees within traditional time frames.

First access. The university has been very successful in providing access to postsecondary education and opportunities to earn a college degree. Consider the academic year 2017-2018. Institutional data indicated that the total enrollment at PFW was 10,139; it consisted of 95.3 percent undergraduates, 4.7 percent graduate students. The class standings of students admitted from high school were distributed as follows: top $10 \%$ of high school class: $11.8 \%$, top $20 \%$ of high school class: $27.3 \%$, top $50 \%$ of high school class: $72.2 \%$, and bottom $50 \%$ of high school class: $27.8 \%$. Enrollment by race and ethnicity is distributed as follows: White $(75.3 \%)$; Racial/ethnic minorities (17.7 \%); two or more races (3.7\%); and International (3.2\%).

However, the success of admitted students, measured by retention and graduation rates, has lagged considerably behind that achieved in access. During 2017-2018, PFW granted a total of 1,805 degrees (17.8\% of the total student body). That pool of degrees consisted of certificates (4.76\%), Associate (5.59\%), Bachelor's (79.17\%), and Master's (10.47\%). Progress toward the achievement of academic degrees is very slow. The fall-to-fall retention is around $62 \%$. Related to this is the fact that it takes our students longer to graduate than would be expected: The fouryear graduate rate in 2011 was $11 \%$; the 5-year graduation rate was $22 \%$, and the 6-year graduation rate was 30\%, approximately. Indeed, institutional data on the university website show four-year, five-year, and six-year graduation rates of the whole campus for the years 2002 through 2011. It can be seen that, on average, the 5-year graduation rate is twice as large as the 4-year graduation rate, and the six-year graduation rate is three times as large as the 4-year graduation rate [15].

The need for building a community. As a consequence of the imbalance between admission rates and success rates, a variety of programs and interventions have been devised and implemented at different levels: by the university as a whole, by specific colleges and schools, and by individual faculty and staff, to help increase learning, retention, and graduation rates. This paper presents experiments by an individual faculty in creating a supportive learning community within a given lecture course to increase student involvement, participation, and learning.

The importance of student involvement and participation. Student involvement in class and campus activities is very important and there is a vast literature on this subject. Astin [4] suggests that students learn more when they are involved in both the academic and social aspects of the school experience. According to this view, learning is most effective when a positive social environment combines with a strong sense of community. Tinto asserts that students require academic, social, and personal support from their school [16]. Other research has supported these ideas over many years [16-21]. 